\section{Present state of the Belgica project Walter Loy}

Vorsink 21, B 9450 Haaltert, Belgium

(walter.loy@skynet.be)

Received January 2011; First published online 28 January 2011

doi:10.1017/S0032247411000064

ABSTRACT. Further progress is reported concerning the preservation of Belgica, currently a wreck in Norwegian waters.

Since the latest note on the Belgica project (Loy 2008), some new investigations have been made concerning the wreck of the ship (Fig. 1).

A mission to the wreck took place on 14 and 15 February 2009 , the purpose of which was to produce a promotion film by a diving team, and to permit salvage and transport companies to estimate the feasibility and systems of raising the wreck. The methods and progress of the removal of the components (iron items, sand, ammunition) still on board of the wreck were discussed. Samples of the seawater near the wreck were taken and analysed.

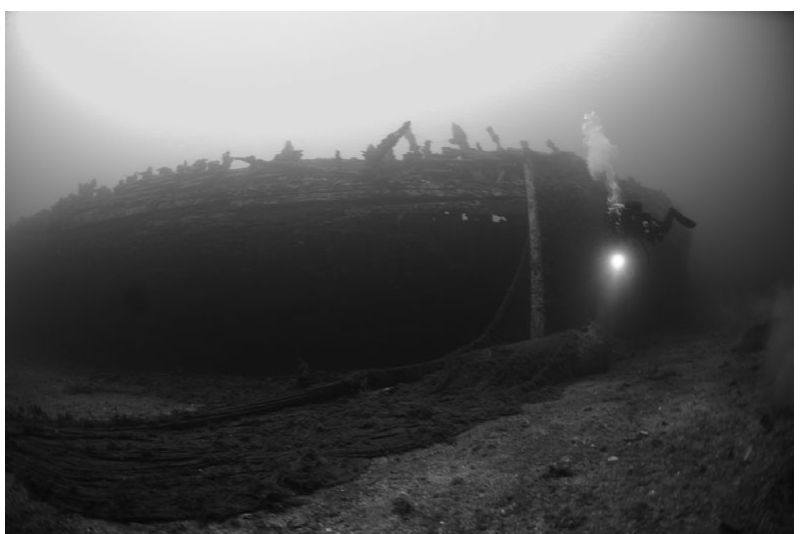

Fig. 1. Photograph of the wreck with fishing nets alongside. Photo by N. Mouchart.
A symposium entitled Conservation of Historic Wrecks for Future Generations was organised in Hasselt University, Belgium, on 26 and 27 October 2009. The report noted that 'monitoring the explosives still on board ... could provide welcome information on the biodegradation and biochemical attenuation processes, data which can be useful for risk assessment of the widespread amount of ammunition still on ocean floors worldwide.' It recommended in situ preservation.

A photoreport on the wreck was made by D. Delbare on 13 and 14 September 2010.

On 25 October a fact finding mission was organised by the Norwegian and Belgian Ministries of Defence and this involved an explosive ordnance disposal (EOD) team. A technical report was prepared by P-Y. Rosoux assessing the quality and quantity of explosives still on board the wreck. His team determined three types of explosives:

TNT explosives (roll shape) in front of the main cargo room, guncotton (nitrocellulose) blocks in the middle and back of the main cargo room,

a few booster explosives (nitrocellulose), type 'Dry field ounce MK2', found beside the wreck.

No detonators were found on the wreck. The quantity of ammunition is estimated by the EOD team as approximately 35 tonnes. All explosives, once dried, are still dangerous. Up to now, the British Navy has not been contacted.

From 18 to 21 October 2010, Dr. Stephen Wickler visited Belgium, accompanied by Kjell Kjaer, vice-chairman of the Belgica Society. Stephen Wickler is responsible for the management of submerged heritage in Tromso University Museum district, Norway. The primary goal of his visit was to obtain an overview of the current status of activities related to the potential raising of Belgica. These were 'satisfied to a considerable extent'. A major issue that remains unresolved is the feasibility of raising the wreck and the impact of removing the explosives on the overall stability of the vessel

In conclusion it can be reported that the good teamwork established between Norway and Belgium continues with a splendid target: the preservation of the historic vessel of A. de Gerlache de Gomery.

\section{Reference}

Loy, W. 2008. A further note on the Belgica project. Polar Record 44(230): 280-281.

\section{Additional documents and survey on the Franklin sites of Beechey Island, Nunavut, Canada: addendum Todd Hansen \\ P.O. Box 30, Berkeley, CA 94701, USA \\ (thansen731@earthlink.net)}

Received October 2010; First published online 28 July 2011

doi: $10.1017 /$ S003224741100012X

In addition to the visits to Beechey Island referenced in my recent article (Hansen 2010), M'Dougall also describes his visit to Beechey Island (in Resolute with De Bray) from Tuesday 10
August 1852 (mistakenly given as 11 August) to Sunday, 15 August (M'Dougall 1857: 78-87). He gives his version of the inscriptions of the three Franklin expedition headboards. While he follows the mistaken placement order as in Osborn and The Illustrated London News of 4 October 1851 (Osborn 1865: 90; The Illustrated London News 1851b), comparison of the inscriptions with both Kane (Kane 1854: 163) and the photo of the Torrington headboard in Powell (Powell 2006: 330, Fig. 10) now lead me to conclude that M'Dougall's rather than Kane's version of the Franklin headboards inscriptions are probably the most accurate of the contemporary accounts.

The account of Sutherland 1852 (Hansen 2010: 194-195) also has a foldout map at the front of volume 2 that includes a detail of Beechey Island (Sutherland 1852: vol. 2 front map). It is similar to that in The Illustrated London News of 20 